\title{
PENGARUH KETERLIBATAN SISWA DALAM KEGIATAN EKSTRAKURIKULER TERHADAP MOTIF BERPRESTASI BELAJAR SISWA DI SMKN 6 BANDUNG
}

\author{
Ronny Mugara \\ ronny_mugara@yahoo.com
}

\author{
Program Studi Pendidikan Matematika, STKIP Siliwangi
}

\begin{abstract}
ABSTRAK
Penelitian ini dilatarbelakangi oleh adanya gejala sebagian siswa yang terlibat dalam kegiatan ekstrakurikuler mempunyai motif berprestasi yang rendah, maka titik permasalahan yang dirumuskan sebagai berikut :" Adakah Pengaruh Keterlibatan Siswa dalam Kegiatan Ekstrakurikuler terhadap Motif Berprestasi Belajar Siswa di SMKN 6 Bandung". Metode yang dipilih adalah penelitian deskriptif kuantitatif, sedangkan pengumpulan data menggunakan angket dengan jawaban tertutup untuk mengukur sajauh mana Pengaruh Keterlibatan Siswa dalam Kegiatan Ekstrakurikuler (Variabel X) terhadap Motif Berprestasi Belajar Siswa di SMKN 6 Bandung (Variabrel Y). Populasi dalam penelitian ini adalah semua siswa kelas $\mathrm{X}$ dan XI yang terlibat dalam kegiatan ektrakurikuler di SMKN 6 Bandung, sedangkan sampelnya adalah sampel total sebanyak 75 orang siswa. Dari hasil perhitungan koefisen korelasi didapat harga $r=0,596$. Dengan demikian, korelasi antara variabel $X$ dan variabel $Y$ termasuk korelasi cukup/ sedang, dan ternyata harga t hitung lebih besar dari t tabel pada taraf siginikansi $95 \%$ dan $90 \%$, sehingga hipotesis yang diajukan diterima. Sedangkan hubungan antara kedua variabel ditandakan dengan bentuk hubungan linier dengan persamaan $\mathrm{Y}=15,58+0,997 \mathrm{X}$. Hubungan tersebut berarti positif, artinya kenaikan variabel $\mathrm{X}$ diikuti oleh kenaikan variabel $\mathrm{Y}$. Harga koefisien determinasi diperoleh sebesar $35,522 \%$. Ini menunjukkan besarnya pengaruh Keterlibatan Siswa dalam Kegiatan Ekstrakurikuler terhadap Motif Berprestasi Belajar Siswa sebesar 35,522 \%, sedangkan sisanya sebesar 64,478\% dipengaruhi oleh faktor lain, dimana pada penelitian ini faktor lain tersebut tidak diteliti. Berdasarkan hasil penelitian ini, dimana besarnya pengaruh keterlibatan siswa dalam kegiatan ekstrakurikuler cukup/ sedang, maka perlu dilakukan langkah-langkah evaluasi bagi pihak-pihak terkait, sehingga para aktivis terus meningkatkan motif berprestasi belajarnya.
\end{abstract}

Kata Kunci: Ekstrakurikuler, Motif Berprestasi

\begin{abstract}
This research is motivated by the presence of symptoms most of the students involved in extracurricular activities had a low achievement motive, then point the problem is formulated as follows: "Is the Effect of Student Involvement in Extracurricular Activities for Student Achievement Motive in SMKN 6 Bandung". The method chosen is descriptive quantitative research, while collecting data using questionnaires with closed answer to gauge where sajauh Influence Student Involvement in Extracurricular Activities (Variable X) for Student Achievement Motive in SMKN 6 Bandung (Variabrel $\mathrm{Y})$. The population in this study were all students of class X and XI are involved in extracurricular activities at SMK 6 Bandung, while the sample is a sample of a total of 75 students. From the calculation of the price obtained correlation coefficient $r=0.596$. Thus, the correlation between the variables $\mathrm{X}$ and $\mathrm{Y}$ include sufficient correlation / medium, and it turns out the price of $\mathrm{t}$ is greater than $\mathrm{t}$ table at level siginikansi $95 \%$ and $90 \%$, so the hypothesis is accepted. While the relationship between these two variables is marked with a linear relationship with the form of the equation $\mathrm{Y}=15.58+0.997 \mathrm{X}$. This relationship means positive, meaning the increase in the variable $\mathrm{X}$ followed by a rise in the variable $\mathrm{Y}$. Price determination coefficient obtained for $35.522 \%$. It shows the influence of Student Involvement in Extracurricular Activities for Student Achievement Motive of $35.522 \%$, while the remaining $64.478 \%$ is influenced by other factors, which in this study such other factors not examined. Based on these results, where the influence of student involvement in extracurricular activities sufficient/ moderate, it is necessary to take measures for the evaluation of the relevant parties, so that activists continue to improve learning achievement motive.
\end{abstract}

Keywords: Extracurricular , Achievement Motive. 


\section{A. PENDAHULUAN}

Lembaga pendidikan mempunyai tugas antara lain mendidik siswanya untuk menjadi cerdas, berwatak susila dan berbudi luhur serta berkemampuan kuat untuk mencapai prestasi. Melalui pendidikan pula diharapkan siswa sebagai subjek pendidikan dapat mengembangkan potensi diri yang dimilikinya. Hingga pada akhirnya siswa tersebut dapat hidup di masyarakat secara mandiri dan mampu memenuhi kebutuhan jasmani maupun rohani.

Hal tersebut sejalan dengan dengan UndangUndang Republik Indonesia Nomor 2 tahun 2003 tentang Sistem Pendidikan Nasional yaitu, Pendidikan Nasional berfungsi mengembangkan kemampuan dan membentuk watak serta peradaban bangsa yang bermartabat dalam rangka mencerdaskan kehidupan bangsa, bertujuan untuk berkembangnya potensi peserta didik, agar menjadi manusia yang beriman dan bertaqwa kepada Tuhan Yang Maha Esa, berakhlak mulia, sehat, berilmu, cakap, kreatif, mandiri, dan menjadi warga negara yang demokratis serta bertanggung jawab.

Pernyataan tersebut menunjukkan bahwa tugas dan tujuan pendidikan selain mendidik siswanya untuk menjadi cerdas, berwatak dan berbudi luhur serta untuk mencapai prestasi, juga berupaya agar siswa dapat mengembangkan potensi diri yang dimilikinya secara optimal. Hal ini mengandung pengertian bahwa perhatian sekolah sebagai lembaga pendidikan tidak menitikberatkan pada aspek kognitif saja, tetapi juga aspek afektif dan psikomotoriknya.

Sunaryo Kartadinata (1983 : 150) mengemukakan bahwa, sekolah tidak hanya menekankan kepada kemapuan kognisi, tetapi kepada mengembangkan segi afeksi dan pengembangan kepribadian secara utuh, sebab dalam proses belajar yang dialami oleh para siswa akan besar pengaruhnya terhadap aspek kognisi, afeksi, psikomotor dan perilaku sosialnya. Aspek kognitif berhubungan dengan perilaku berfikir, mengetahui dan memecahkan masalah. Aspek afektif berhubungan dengan sikap, nilainilai, apresiasi dan penyesuaian perasaan sosial. Sedangkan aspek psikomotor berhubungan keterampilan yang bersifat manual dan motorik.

Sekolah dalam penyelenggaraan proses pendidikannya selain melalui bidang pengajaran yang secara operasional tertuang dalam kegiatan proses belajar mengajar, juga melalui kegiatan siswa di luar jam pelajaran efektif sekolah, kegiatan ini dinamakan ekstrakurikuler. Kegiatan ekstrakurikuler menurut Permen Dikbud no.62 tahun 2014 adalah kegiatan kurikuler yang dilakukan oleh peserta didik di luar jam belajar kegiatan intrakurikuler dan kegiatan kokurikuler, di bawah bimbingan dan pengawasan satuan pendidikan.

Keterlibatan siswa dalam kegiatan ektrakurikuler diharapkan dapat memberikan sumbangan yang positif, seperti yang diungkapkan Oteng Sutisna (1989 : 125) bahwa, keterlibatan remaja dalam kegiatan ekstrakurikuler memberikan manfaat seperti pemanfaatan waktu senggang yang efektif, belajar berinteraksi dengan orang lain, mengembangkan inisiatif dan tanggung jawab, memupuk ikatan persahabatan dan persaudaraan dan membangun gairah dan minat yang sehat terhadap belajar. Sehingga dengan aktifitasnya, remaja lebih memfokuskan diri pada belajar dan kegiatan bermakna.

Berdasarkan uraian diatas, kegiatan ekstrakurikuler mempunyai peranan cukup penting dalam upaya membantu mengarahkan dan menyalurkan aktifitas-aktifitas siswa ke arah yang positif. Siswa SMK yang pada umumnya tergolong masa remaja memerlukan perhatian, ruang gerak serta fasilitas untuk menyalurkan kebutuhan yang dirasakan olehnya, baik yang bersifat fisik maupun psikis, dan salah satunya mengacu kepada motif berprestasi. Motif berprestasi dapat diperoleh dari pengalaman berinteraksi dengan lingkungan. Pengalaman ini akan mudah didapat bila seorang siswa terlibat aktif dalam kegiatan-kegiatan ekstrakurikuler sekolah. Kegiatan ekstrakurikuler dapat memperluas wawasan berfikir, daya kreatifitas, minat dan bakat maupun keterampilan siswanya. Dari sudut pandang inilah keterlibatan siswa dalam kegiatan ekstrakurikuler dapat menunjang terhadap prestasi belajar siswa, karena dalam pelaksanaan kegiatan ektrakurikuler siswa selalu melibatkan unsur-unsur pengetahuan, diantaranya pemakaian metode seminar, diskusi ilmiah serta unsur kreativitas siswa.

Dari uraian diatas timbul suatu pertanyaan, adakah pengaruh keterlibatan siswa dalam kegiatan ekstrakurikuler terhadap motif berprestasi belajar siswa di SMKN 6 Bandung? Jika ada seberapa besar pengaruhnya? Untuk menjawab pertanyaan tersebut perlu diadakan suatu penelitian. Penelitian tersebut dilakukan untuk membuktikan benar atau tidaknya keterlibatan siswa dalam kegiatan 
ekstrakurikuler berpengaruh terhadap motif berprestasi belajar siswa di SMKN 6 Bandung. Berdasarkan pada uraian diatas, maka penulis tertarik melakukan penelitian tentang Pengaruh Keterlibatan Siswa dalam Kegiatan Ekstrakurikuler terhadap Motif Berprestasi Belajar Siswa di SMKN 6 Bandung. Adapun tujuan dari penelitian ini adalah: (1) Untuk memperoleh gambaran umum mengenai keterlibatan siswa dalam kegiatan ekstrakurikuler di SMKN 6 Bandung, (2) Untuk memperoleh gambaran umum mengenai motif berprestasi belajar siswa yang terlibat dalam kegiatan ekstrakurikuler di SMKN 6 Bandung, (3) Untuk memperoleh gambaran seberapa besar pengaruh keterlibatan siswa dalam kegiatan ekstrakurikuler terhadap motif berprestasi belajar siswa di SMKN 6 Bandung.

\section{B. KAJIAN TEORI DAN METODE}

\section{Kajian Teori}

\section{a. Keterlibatan Siswa dalam Kegiatan Ekstrakurikuler}

Kegiatan ekstrakurikuler sebagai salah satu jalur pembinaan kesiswaan dan penunjang kegiatan belajar, tentunya tidak terlepas dari berbagai pemahaman semua pihak, baik siswa, pendidik maupun orang tua. Oleh karena itu ada baiknya bila terlebih dahulu mengemukakan pengertian tersebut. Secara umum kegiatan ekstrakurikuler adalah kegiatan di luar jam pelajaran sekolah biasa, seperti pernyataan Karso (Sri Wiyanti, 2000 : 26) mengemukakan: "Kegiatan ekstrakurikuler dilakukan di luar jam pelajaran tatap muka termasuk pada waktu libur, diikuti seluruh siswa atau sebagian siswa menurut jenis dan fungsinya". Sejalan dengan pengertian diatas, Dewa Ketut S, Desak Made S (1990:98) menyatakan "kegiatan esktrakurikuler merupakan bentuk kegiatan yang dilakukan siswa di luar jam tatap muka, dilaksanakan baik di sekolah maupun di luar sekolah. Kegiatan ekstrakurikuler yang dilakukan baik di sekolah maupun di luar sekolah bertujuan agar siswa dapat lebih memperkaya dan memperluas wawasan pengetahuan, mendorong pembinaan sikap dan/ atau nilai-nilai dalam rangka penerapan pengetahuan dan kemampuan yang telah dipelajari dari berbagai mata pelajaran dalam kurikulum, baik program inti maupun program non inti.

Dari beberapa pengertian diatas, dapat ditarik kesimpulan bahwa kegiatan ekstrakurikuler merupakan kegiatan berupa pengayaaan, pendalaman dan perbaikan yang berkaitan dengan program kurikuler, penyaluran bakat dan minat serta pelengkap pembinaan manusia seutuhnya, yang diselenggarakan di luar jam pelajaran biasa, baik di sekolah ataupun di luar sekolah.

Adapun tujuan kegiatan ekstrakurikuler secara umum tidak jauh beda dengan tujuan kegiatankegiatan lainnya, seperti tujuan dari belajar yaitu mampu menciptakan individu yang dewasa. Begitu juga dengan kegiatan ekstrakurikuler yang secara langsung atau tidak langsung bertujuan untuk mendidik/ membina individu menjadi dewasa. Untuk itu maka sebelum melaksanakan kegiatan terlebih dahulu ditetapkan tujuan yang akan dicapai. Depdikbud (2014:2) merumuskan tujuan kegiatan ekstrakurikuler yaitu, Kegiatan Ekstrakurikuler diselenggarakan dengan tujuan untuk mengembangkan potensi, bakat, minat, kemampuan, kepribadian, kerjasama, dan kemandirian peserta didik secara optimal dalam rangka mendukung pencapaian tujuan pendidikan nasional.

Oteng Sutisna (1989 : 57) menjabarkan tujuan kegiatan siswa tersebut menjadi tujuan yang bersifat individual, sosial, sivik dan etis meliputi:

1) Tujuan individual

a) Menggunakan waktu senggang dan konstruktif

b) Mengembangkan kepribadian

c) Memperkaya kepribadian

d) Mencapai realisasi diri untuk maksudmaksud baik.

e) Mengembangkan inisitif dan tanggung jawab.

f) Belajar memimpin dan turut aktif dalam pertemuan-pertemuan

g) Menyediakan kesempatan bagi penilaian diri

2) Tujuan Sosial

a) Memberikan rekreasi mental dan fisik yang sehat

b) Memperoleh pengalaman dalam bekerja dengan orang lain

c) Mengembangkan tanggung jawab kelompok yang demokratis

d) Belajar mempraktekkan hubungan manusia yang baik

e) Memahami proses kelompok

f) Memupuk hubungan murid-guru yang baik

g) Menyediakan kesempatan bagi partisipasi murid-guru

h) Meningkatkan hubungan-hubungan sosial. 
3) Tujuan Sivik dan Etis

a) Memupuk ikatan persaudaraan diantara murid-murid tanpa membedakan daerah, suku, agama, satatus ekonomi dan kesanggupan.

b) Membangun minat gairah murid terhadap program sekolah

c) Menyediakan sarana dimana murid dapat menyumbang kepada kesejahteraan dirinya.

d) Menyediakan kesempatan bagi murid untuk mempelajari dan mempraktekkan keterampilan, nilai dan sikap yang diakui sebagai tujuan pendidikan kewarganegaraan yang layak.

Berdasarkan tujuan-tujuan tersebut diatas, maka dapat ditarik kesimpulan bahwa tujuan pokok dari kegiatan ektrakurikuler agar siswa dapat:

a. Menggunakan waktu senggang dengan kegiatan yang positif

b. Mengembangkan dan memperkaya kepribadian

c. Mengembangkan inisiatif dan tanggung jawab

d. Belajar berpartisipasi aktif dalam pertemuan formal maupun non-formal

e. Belajar bersosialisasi baik dengan sesama teman maupun dengan guru.

f. Memperdalam dan mempraktekkan pengetahuan dan wawasan serta keterampilan siswa

Sesuai dengan uraian diatas, maka dapat dikatakan bahwa tujuan kegiatan ektrakurikuler pada dasarnya adalah menyalurkan minta khusus siswasiswanya pada hari belajar maupun pada hari libur panjang dengan jalan memberikan pengetahuan, keterampilan serta latihan sehingga dapat menunjang kegiatan belajar mengajar di sekolah.

\section{b. Motif Berprestasi}

\section{1) Pengertian Motif Berprestasi}

M. Buchari (1978:25), menyatakan bahwa :" salah satu faktor yang mempengaruhi hasil perbuatan belajar yang baik adalah motif berprestasi". Motif berprestasi yang baik adalah motif berprestasi yang timbul karena keinginan yang kuat untuk memperoleh hasil belajar. Motif berprestasi merupakan salah satu faktor yang mendorong kegiatan belajar. Namun demikian, tidak sedikit siswa yang mengalami kesulitan belajarnya, sehingga mereka tidak mampu mengoptimalkan kemampuan mereka dalam mencapai prestasi.
Konsep motif berprestasi, pertama kali dipopulerkan oleh Mc.Clelland dengan nama nAch singkatan dari "need for achievement". nAch ini menurut Mc. Clelland laksana virus metal yang menulari seseorang, sehingga ia cenderung berperilaku aneh-aneh. Seseorang yang mempunyai motif berprestasi mau berbuat lebih baik dari orang lain, atau mengerjakan sesuatu lebih baik dari pekerjaan sebelumnya. Ini berarti bahwa motif berprestasi merupakan suatu kompetisi ke arah ukuran yang baik. Motif berprestasi tidak selamanya tampak, namun diharapkan menampakkan diri dengan sendirinya di dalam perilaku berprestasi seseorang. Menurut De Cecco (Eddy Subandrijo, 1990 : 27), mengemukakan bahwa :"Motif berprestasi adalah suatu harapan untuk memperoleh kepuasan dengan menguasai tugas-tugas yang sukar dan menantang.

Dari beberapa pendapat mengenai motif berprestasi yang dikemukakan di atas berbedabeda pada masing-masing ahli, namun pada dasarnya pendapat mereka sama, yakni motif berprestasi merupakan dorongan yang terdapat dalam diri seseorang untuk mengerjakan suatu pekerjaan yang lebih baik, sehingga hasil pekerjaannya itu merupakan hasil yang terbaik. Motif berprestasi pada diri seseorang dapat dilihat dari beberapa ciri atau karakteristiknya.

\section{2) Karakteristik Motif Berprestasi}

Menurut Murray (Ambo Enre Abdullah, 1979 : 47), menyatakan bahwa : "Motif berprestasi sebagai suatu kekuatan yang ada pada diri seseorang, diarahkan untuk melakukan kegiatan sebagai berikut :

a) Menyelesaikan sesuatu yang sukar

b) Menguasai, memanipulasi atau mengorganisasikan obyek-obyek fisik, manusia atau gagasan-gagasan.

c) Melakukan sesuatu dengan cepat, bebas dan memungkinkan

d) Mengatasi rintangan-rintangan dan mencapai suatu standar yang tinggi

e) Mengunggulkan diri sendiri

f) Mengatasi orang lain

g) Meningkatkan harga diri dengan kesuksesan dalam melatih dan menggunakan kemampuan khusus.

Motif berprestasi pada setiap individu sifatnya bervariasi, ada individu yang memiliki tingkat motif berprestasi tinggi dan ada pula yang rendah. Dalam hubungannya dengan hal tersebut, Dadang 
Sulaeman (1978 : 56-57) mengutip pendapat Johnson dan Kolb yang mengemukakan bahwa kakteristik individu yang mempunyai motif berprestasi tinggi mempunyai ciri-ciri sebagai berikut:

(1) Ia mempunyai situasi atau tugas yang menuntut tangung jawab pribadi atas hasilhasilnya dan bukan atas dasar untunguntungan, nasib atau kebetulan.

(2) Ia memiliki tujuan-tujuan yang realistk tapi menantang, daripada tujuan-tujuan yang terlalu mudah dicapai atau terlalu besar resikonya.

(3) Ia mencari situasi-situasi atau pekerjaanpekerjaan di mana ia memperoleh umpan balik dengan segera dan nyata untuk membentuk baik tidaknya suatu pekerjaan.

(4) Ia senang bekerja sendiri dan bersaing untuk mengungguli orang lain.

(5) Ia mampu menangguhkan pemuasan keinginan-keinginannya demi masa depan yang lebih baik.

(6) Ia tidak tergugah untuk sekedar mendapatkan uang, status atu keunggulan lainnya. Ia akan mencarinya.

Hasil penelitian Mc Clelland yang dikutip Dedi Suryadi (1995 : 19) membuat kesimpulan individu yang mempunyai orientasi tinggi terhadap prestasi, antara lain sebagai berikut :

(a) Orang yang tinggi motif berprestasinya cenderung lebih didorong oleh harapan sukses sebagaimana ditunjukkan sensivitasnya terhadap kata-kata yang menunjukkan kesuksesan, dan lebih baik ingatannya terhadap tugas-tugas yang telah diselesaikan.

(b) Pada umumnya orang yang tinggi motif berprestasinya cenderung lebih tinggi skornya dalam tugas-tugas melengkapi dengan kondisi yang berorientasi pada prestasinya.

(c) Yang tergolong sedang motif berprestasinya, lebih cenderung didorong oleh perasaan takut gagal, cenderung mengingat-ingat tugas yang terselesaikan dan menolak kata-kata yang menunjukkan kegagalan.

Karakteristik tersebut bersifat universal dan bisa dimiliki oleh siapa saja yang ingin mencapai prestasi tinggi dalam pekerjaannya termasuk siswa. Suatu ciri penting dari teori motif berprestasi Mc. Clelland adalah kebutuhan itu dapat dipelajari. Pertanyaan tersebut sebagaimana dikemukakan Liliana (1995 : 26) bahwa "Motivasi berprestasi dapat diajarkan melalui berbagai bentuk latihan". Oleh karena itu teorinya sering disebut Learned
Needs Theory atau teori kebutuhan yang dapat dipelajari. Ia berpendapat bahwa motivasi merupakan suatu pengalaman belajar yang terbentuk dalam suatu situasi yang mengandung suasana afeksi. Dalam hal ini semakin jelas bahwa motif berprestasi yang dimiliki seorang individu dipengaruhi oleh intensitas suasana afeksi yang membentuknya.

\section{3) Pengukuran Motif Berprestasi}

Motif bukanlah hal yang dapat diamati secara langsung, hanya dapat diidentifikasikan melalui efek tingkah laku yang nyata. Hal ini dipertegas oleh Abin Syamsudin Makmun (2000 : 40) yang mengemukakan bahwa :"Meskipun motivasi itu merupakan suatu substansi yang secara eksplisit dapat kita mati, tetapi yang dapat kita lakukan adalah mengidentifikasikan beberapa indikator".

Indikator-indikator tersebut adalah :

a) Durasi kegiatan (seberapa lama kemampuan penggunaan waktunya untuk melakukan kegiatan).

b) Frekuensi kegiatan (seberapa sering kegiatan dilakukan dalam periode waktu tertentu).

c) Presistensinya (ketepatan dan kelekatan) pada tujuan kegiatannya.

d) Devosi (pengabdian) dan pengorbanan ( uang, tenaga, pikiran, bahkan jiwa ataupun nyawanya) untuk mencapai tujuan

e) Tingkatan aspirasinya (maksud, rencana, citacita, sasaran atau target dan idolanya) yang hendak dicapai dengan kegiatan yang dilakukannya.

f) Tingkatan kualifikasi dan prestasi atau produk yang dicapai dari kegiatannya (seberapa banyak, memadai atau tidak, memuaskan atau tidak).

g) Arah sikapnya terhadap sasaran kegiatan positif atau negatif.

Mc.Clelland dan kawan-kawan berhasil mengembangkan instrumen untuk mengukur aspek-aspek motif berprestasi yaitu TAT (Thematic Apperception Test) model Murray dan Morgan. Menurut Dadang Sulaeman (1978 59) cara terbaik untuk mengetahui pengaruh positif, termasuk motif berprestasi ialah melalui fantasi yaitu tes yang terdiri dari sejumlah gambar yang harus diceritakan oleh responden.

Berdasarkan cerita yang telah dibuatnya itu motif berprestasi dapat diketahui. Cerita yang menunjukkan adanya khayalan atau fantasi 
berprestasi menggambarkan seseorang (pelaku dalam cerita itu) berusaha untuk :

(1) Melakukan sesuatu lebih baik dari orang lain

(2) Mencapai atau melebihi ukuran keberhasilan yang ditetapkan sendiri

(3) Mencari hasil yang luar biasa dan khas

(4) Mengaitkan dan melibatkan diri pada karir masa depan

Dari cerita itu, apabila responden telah memenuhi salah satu atau beberapa ciri seperti disebutkan di atas, maka cerita tersebut diberi nilai positif $(+1)$. Sedangkan apabila tidak satu ciri pun terdapat didalamnya, maka motif berprestasinya tidak perlu diberi nilai lebih jauh.

Alat pengukuran motif berprestasi dengan TAT menurut Mc.Clelland ini hanya dapat digunakan oleh seorang psikolog yang ahli dalam bidang tersebut. Oleh sebab itu, dalam penelitian ini penulis mempergunakan alat pengumpul data berupa angket yang berbentuk skala sikap dari Likert. Tetapi untuk mengukur motif berprestasi ini dapat juga digunakan sikap skala.

\section{Metode}

\section{a. Metode Penelitian}

Metode penelitian yang dipakai dalam penelitian ini adalah metode deskriptif kuantitaif, yaitu suatu metode pendekatan penelitian pada masa sekarang. Seperti yang dikemukakan oleh Moh.Nasir (1985 : 42) yaitu sebagai berikut : "Metode deskriptif adalah suatu metode dalam meneliti status kelompok manusia, obyek, suatu kondisi, suatu system pemikiran ataupun sesuatu peristiwa pada masa sekarang”. Sedangkan Sanafiah Faisal (1982: 42) secara lebih terperinci mengemukakan bahwa:

Penelitian deskriptif tujuannya mendeskripsikan apa-apa yang terjadi pada saat ini. Didalamnya terdapat upaya pencacatan, deskripsi, analisis dan menginterpretasikan kondisi-kondisi yang sekarang terjadi atau ada. Pada penelitian deskriptif ini, didalamnya termasuk berbagai tipe perbandingan dan mungkin juga sampai pada usaha menemukan hubungan yang terdapat diantara variabel-variabel.

Sedangkan menurut Winarno Surakhmad (1990 : 140), metode deskriptif mempunyai ciri-ciri sebagai berikut :
1) Memusatkan diri pada pemecahan masalah yang ada pada masa sekarang, pada masalahmasalah yang aktual.

2) Data yang dikumpulkan mula-mula disusun, dijelaskan dan kemudian dianalisis (karena itu metode ini disebutt metode analitik).

Berdasarkan kutipan diatas dapat ditarik kesimpulan bahwa metode deskriptif kuantitatif cocok digunakan dalam penelitian ini, karena sejalan dengan maksud penelitian, yakni untuk memecahkan dan mengungkapkan permasalahan yang ada pada saat penelitian dilakukan, yakni tentang pengaruh keterlibatan siswa pada kegiatan ekstrakurikuler terhadap motif berprestasi belajar siswa di Sekolah Menengah Kejuruan (SMK) Negeri 6 Bandung.

\section{b. Variabel dan Paradigma Penelitian}

Berdasarkan identifikasi masalah dan rumusan masalah dalam penelitian ini, variabel penelitian dapat ditentukan sebagai berikut :

1) Variabel bebas $(X)$ adalah keterlibatan siswa dalam kegiatan ekstrakurikuler.

2) Variabel terikat $(Y)$ adalah motif berprestasi belajar siswa SMKN 6 Bandung.

Secara umum paradigma penelitian digambarkan sebagai berikut :

\section{PARADIGMA PENELITIAN}

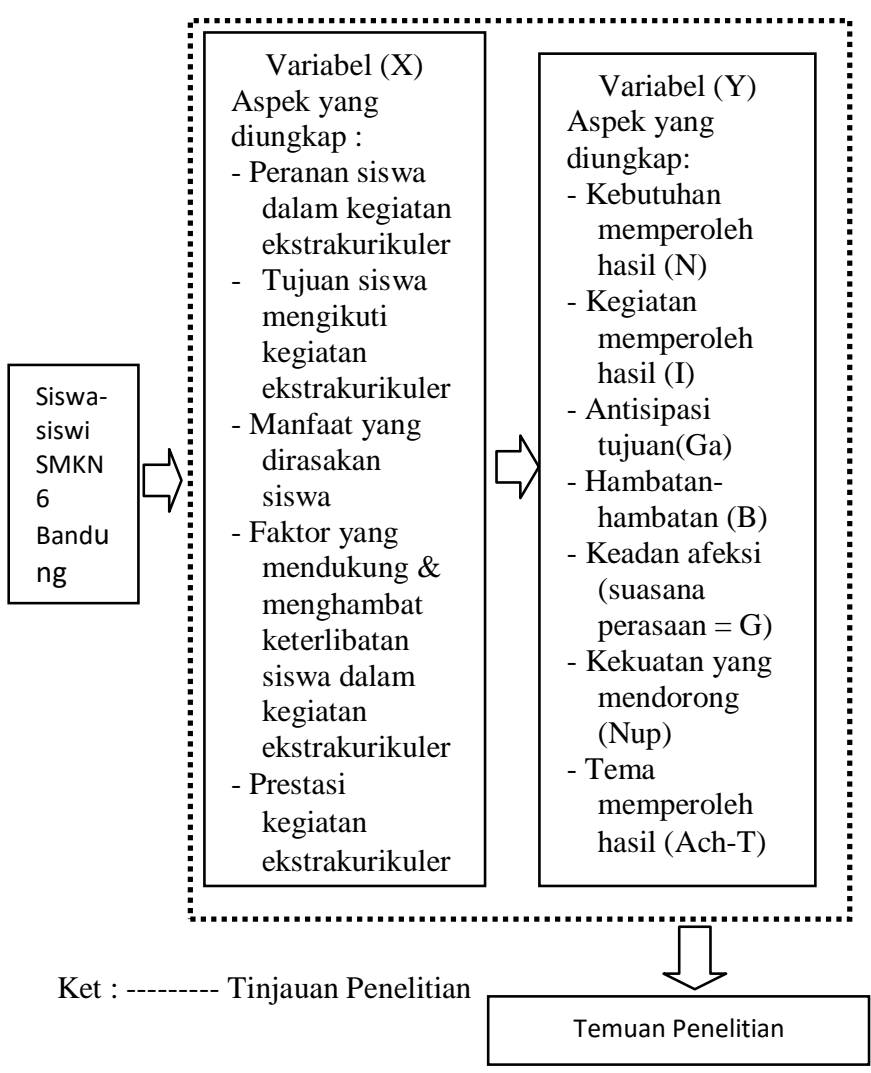




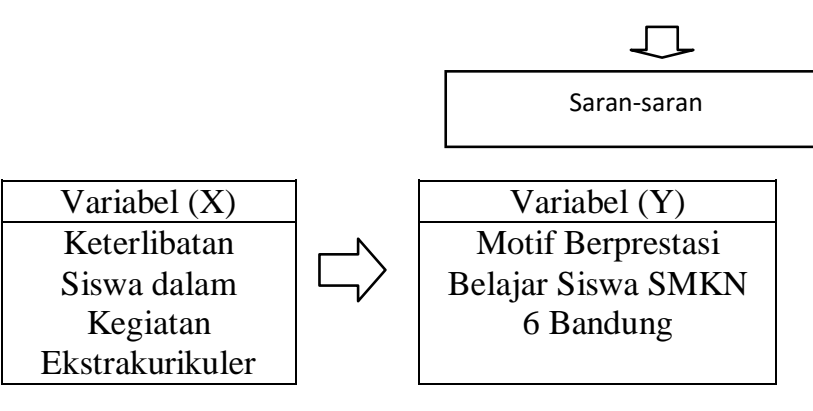

Alur Hubungan Antar Variabel

c. Populasi dan Sampel

Sesuai dengan lingkup penelitian, populasi atau wilayah data yang menjadi subyek penelitian adalah siswa SMKN 6 Bandung yang aktif terlibat dalam kegiatan ekstrakurikuler di lingkungan sekolah dimulai dari mulai berdirinya sekolah sampai sekarang. Mengingat metode yang digunakan adalah metode deskriptif kualitatif, maka sampel yang digunakan adalah siswa yang aktif pada saat ini. Berdasarkan hasil observasi, jumlah populasi penelitian ini sebanyak 75 orang, yang aktif di berbagai organisasi yang berada di lingkungan SMKN 6 Bandung.

Menurut Suharsimi Arikunto (2002 : 112) mengenai penarikan sampel adalah sebagai berikut: "Untuk sekedar ancer-ancer maka apabila subjeknya kurang dari 100, lebih baik diambil semua sehingga penelitiannya merupakan penelitiannya merupakan penelitian populasi. Selanjutnya, jika jumlah subjeknya besar dapat diambil antara $10-15 \%$ atau $20-25 \%$ atau lebih ...."

Sedangkan menurut Nana Sudjana ( 1991: 73) dijelaskan bahwa : "Minimal sampel sebanyak 30 subyek. Ini didasarkan atas perhitungan atau syarat pengujian yang lazim digunakan dalam statistika”.

Berdasarkan pendapat di atas dan melihat jumlah populasi dalam penelitian ini relatif kecil, maka diambil seluruh populasi sebagai sampel, yaitu sebanyak 75 orang

\section{d. Teknik Pengumpulan Data dan Uji Instrumen Penelitian}

Teknik pengumpulan data yang digunakan dalam penelitian ini adalah angket, yaitu sejumlah pertanyaan tertulis yang digunakan untuk memperoleh informasi dari responden. Angket dalam penelitian ini disediakan untuk kedua variabel penelitian.

Sesuai dengan teknik pengumpulan data yang dipergunakan angket, maka instrumen yang dipakai adalah angket pula. Data yang dijaring melalui angket merupakan data primer yang berhubungan langsung dengan masalah yang akan dipecahkan.

Pada penelitian ini digunakan 2 macam angket berdasarkan variabel-variabel penelitian, yakni Keterlibatan Siswa dalam Kegiatan Ekstrakurikuler (variabel X ) dan (variabel Y) Motif Berprestasi Belajar Siswa di SMKN 6 Bandung

\section{HASIL DAN PEMBAHASAN}

\section{Deskripsi Data}

Setelah instrumen penelitian dikumpulkan dari responden, kemudian hasilnya diberi skor untuk setiap item dari seluruh responden, serta dihitung jumlah skornya untuk tiap-tiap variabel.

Berdasarkan data yang diperoleh untuk dua buah variabel penelitian didapat hasilnya sebagai berikut :

a. Variabel X (Keterlibatan Siswa dalam Kegiatan Ekstrakurikuler)

- Banyak responden $(\mathrm{N}) \quad=45$

- Skor tertinggi = 33

- Skor terrendah $\quad=11$

- Simpangan baku (SD) $\quad=5,480$

- Skor rata-rata $(\mu) \quad=23,789$

Setelah data menjadi skor baku disusun dalam bentuk tabel frekuensi berikut:

Tabel 1. Distribusi Frekuensi Variabel $X$

\begin{tabular}{cccc}
\hline NO & Interval & $\begin{array}{c}\text { Frekuensi } \\
\text { Absolut }\end{array}$ & $\begin{array}{c}\text { Frekuensi } \\
\text { Relatif } \\
(\%)\end{array}$ \\
\hline 1 & $11-14$ & 2 & 4,44 \\
2 & $15-18$ & 6 & 13,33 \\
3 & $19-22$ & 10 & 22,22 \\
4 & $23-26$ & 13 & 28,89 \\
5 & $27-30$ & 8 & 17,78 \\
6 & $31-34$ & 6 & 13,33 \\
& Jumlah & 45 & 100 \\
\hline
\end{tabular}

Sebagai visualisasi dari tabel frekkuensi kesesuaian persepsi tentang peluang kerja disajikan dalam bentuk diagram batang di bawah ini : 


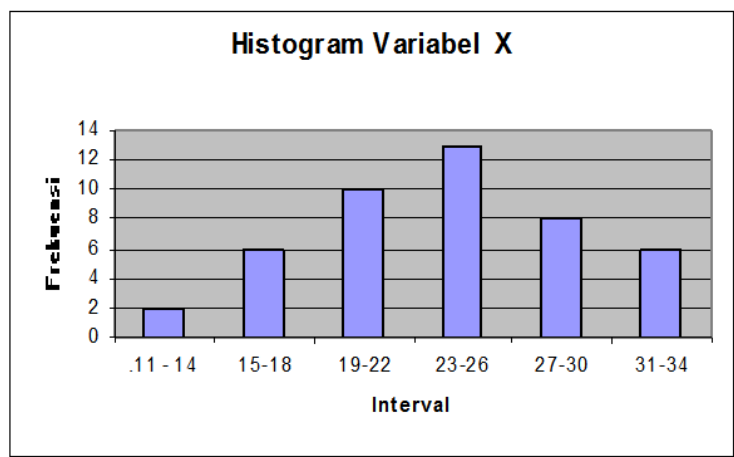

\section{Gambar 1. Grafik Distribusi Frekuensi Variabel X}

b. Variabel Y (Motif Berprestasi).

$\begin{array}{ll}\text { Banyak responden }(\mathrm{N}) & =45 \\ \text { Skor tertinggi } & =61 \\ \text { Skor terendah } & =15 \\ \text { Simpangan baku }(\mathrm{SD}) & =11,001 \\ \text { Skor rata-rata }(\mu) & =40,9\end{array}$

Setelah data menjadi skor baku disusun dalam bentuk tabel frekuensi berikut:

Tabel 2. Distribusi Frekuensi Variabel Y

\begin{tabular}{cccc}
\hline NO & Interval & $\begin{array}{c}\text { Frekuensi } \\
\text { Absolut }\end{array}$ & $\begin{array}{c}\text { Frekuensi } \\
\text { Relatif } \\
(\%)\end{array}$ \\
\hline 1 & $15-22$ & 3 & 6,667 \\
2 & $23-30$ & 6 & 13,33 \\
3 & $31-38$ & 7 & 15,56 \\
4 & $39-46$ & 14 & 31,11 \\
5 & $47-54$ & 11 & 24,444 \\
6 & $55-62$ & 4 & 8,889 \\
& Jumlah & 45 & 100 \\
\hline
\end{tabular}

Sebagai visualisasi dari tabel frekkuensi kesesuaian persepsi tentang peluang kerja disajikan dalam bentuk diagram batang di bawah ini :

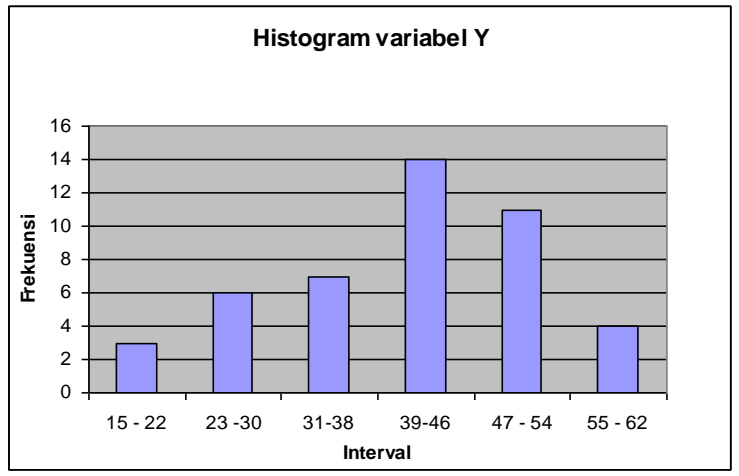

Gambar 2. Grafik Distribusi Frekuensi variabel $\mathbf{Y}$

\section{Analisis Data}

Analisis data dilakukan dengan menguji data yang diperoleh dengan menggunakan statistik analitik. Selanjutnya analisis data dipergunakan untuk menguji hipotesis.

Prosedur pengujian hipotesis dilakukan sesuai dengan teknik pengolahan data atau analisis data sebagaimana telah diuraikan sebelumnya langkahlangkah pembahasannya adalah sebagai berikut :

\section{a. Uji Normalitas Distribusi Frekuensi}

1) Uji normalitas distribusi frekuensi variabel $x$ dilakukan dengan uji chi-kuadrat, diperoleh harga $x^{2}$ hitung sebesar 1,496 Hasil perhitungan tersebut dikonsultasikan ke dalam bentuk tabel $\mathrm{x}^{2}$ (lampiran), dari tabel diperoleh $\mathrm{x}^{2}(0,90)(3)=$ 6,25 . Ternyata $x^{2}$ hitung $<x^{2}$ tabel, maka dapat disimpulkan bahwa penyebaran skor variabel $\mathrm{x}$ normal pada tingkat kepercayaan $90 \%$ dengan derajat kebebasan $(\mathrm{dk})=3$.

2) Uji normalitas distribusi frekuensi variabel $Y$ dilakukan dengan uji Chi-Kuadrat, diperoleh harga $x^{2}$ hitung sebesar 2,922. Hasil perhitungan tersebut dikonsultasikan ke dalam tabel $\mathrm{x}^{2}$ (lampiran) dari tabel diperoleh $\mathrm{x}^{2}$ $(0,90)(3)=6,25$. Ternyata $x^{2}$ hitung $<x^{2}$ tabel, maka dapat disimpulkan bahwa penyebaran skor variabel y normal, pada tingkat kepercayaan $90 \%$ dengan derajat kebebasan $(\mathrm{dk})=3$.

\section{b. Perhitungan Homogenitas}

Uji homogenitas ini dilakukan untuk menguji apakah sampel berasal dari populasi yang sama atau tidak. Dari hasil uji homogenitas variabel $\mathrm{x}$ dengan tes Bartlett, diperoleh harga $\mathrm{x}_{\text {hitung }}^{2}$ sebesar

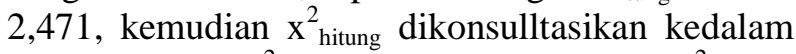
tabel distribusi $\mathrm{x}^{2}$. Dari tabel didapat harga $\mathrm{x}_{(0,95)(1)}$ $=3,84$. Dan ternyata harga $x_{\text {hitung }}^{2}<x_{\text {tabel }}^{2}$, sehingga dapat disimpulkan bahwa sampel homogen pada tingkat kepercayaan $95 \%$ dengan derajat kebebasan (1).

Dari hasil uji homogenitas variabel y dengan tes Bartlett, diperoleh harga $\mathrm{x}^{2}{ }_{\text {hitung }}$ sebesar 3,645, kemudian $\mathrm{x}^{2}$ hitung dikonsulltasikan kedalam tabel distribusi $x^{2}$. Dari tabel didapat harga $x_{(0,95)(1)}^{2}=$ 3,84 . Dan ternyata harga $x_{\text {hitung }}<x^{2}{ }_{\text {tabel }}$, sehingga dapat disimpulkan bahwa sampel homogen pada tingkat kepercayaan $95 \%$ dengan derajat kebebasan (1). 


\section{c. Uji Kecenderungan}

Uji kecenderungan dimaksudkan untuk mengetahui kecenderungan dan gambaran umum Keterlibatan Siswa dalam Kegiatan Ekstrakurikuler dan Motif Berprestasi.

1) Gambaran Umum Keterlibatan Siswa dalam Kegiatan Ekstrakurikuler

Berdasarkan hasil perhitungan Uji Kecenderungan (terlampir), diperoleh hasil gambaran umum keterlibatan siswa dalam kegiatan ekstrakurikuler dapat dilihat dalam tabel berikut :

Tabel 3. Gambaran Umum Keterlibatan Siswa dalam Kegiatan Ekstrakurikuler

\begin{tabular}{cccl}
\hline $\begin{array}{c}\text { Rentang } \\
\text { Skor }\end{array}$ & Frekuensi & $\%$ & Kriteria \\
\hline$\geq 22$ & 31 & 68,889 & Tinggi \\
$15-22$ & 11 & 24,444 & Sedang \\
$\leq 15$ & 3 & 6,667 & Rendah \\
\hline
\end{tabular}

Dari tabel diatas dapat diketahui bahwa kategori tinggi sebesar $68,889 \%$, kategori sedang sebesar $24,444 \%$ dan kategori rendah sebesar 6,667 \%. Jadi dapat dikatakan bahwa gambaran umum keterlibatan siswa dalam kegiatan ekstrakurikuler termasuk dalam kategori tinggi. Untuk lebih jelasnya gambaran tersebut dapat divisualisasikan ke dalam grafik batang sebagai berikut:

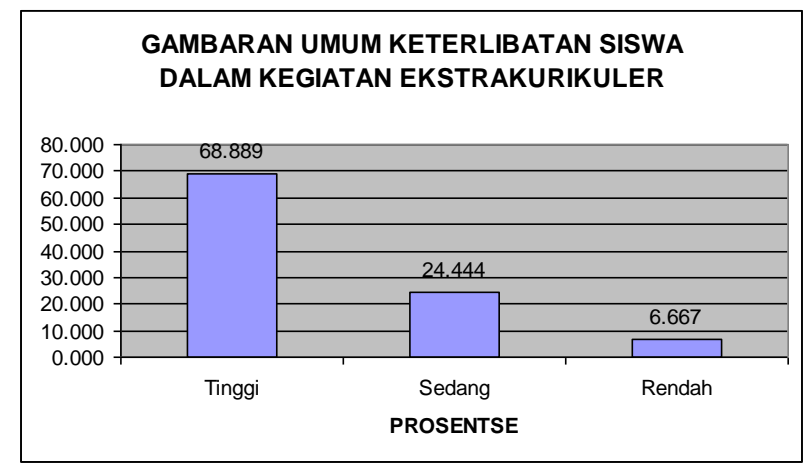

Gambar 3. Grafik Gambaran Umum

Keterlibatan Siswa dalam Kegiatan Ekstrakurikuler

\section{2) Gambaran Umum Motif Berprestasi}

Berdasarkan hasil perhitungan untuk skor motif berprestasi dengan menggunakan skor ideal, maka gambaran umum motif berprestasi dapat dilihat dalam tabel berikut:
Tabel 4. Gambaran Umum Motif Berprestasi

\begin{tabular}{|c|c|c|l|}
\hline $\begin{array}{c}\text { Rentang } \\
\text { Skor }\end{array}$ & Frekuensi & $\%$ & Kriteria \\
\hline$\geq 54$ & 4 & 8,889 & Tinggi \\
$36-54$ & 26 & 57,778 & Sedang \\
$\leq 36$ & 15 & 33,333 & Rendah \\
\hline
\end{tabular}

Dari tabel diatas dapat diketahui bahwa kategori tinggi sebesar 8,889\%, kategori sedang sebesar $57,778 \%$ dan kategori rendah sebesar 33,333\%. Jadi dapat dikatakan bahwa gambaran umum motif berprestasi belajar siswa di SMKN 6 Bandung termasuk dalam kategori sedang. Untuk lebih jelasnya gambaran tersebut dapat divisualisasikan ke dalam grafik batang sebagai berikut:

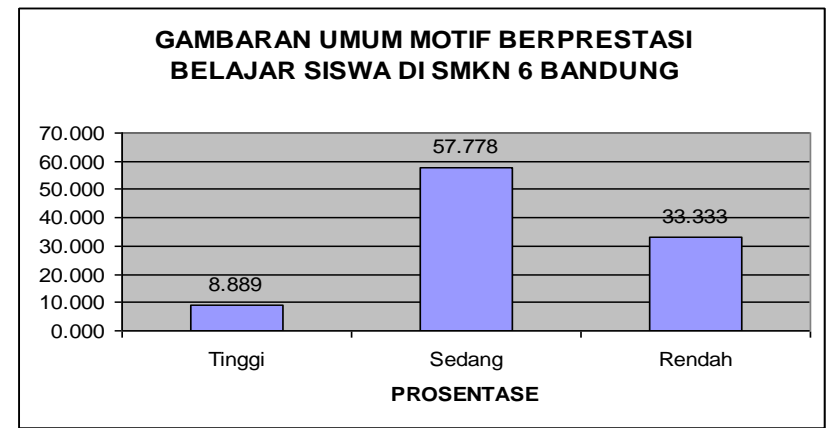

Gambar 4. Grafik Gambaran Umum Motif Berprestasi Belajar Siswa SMKN 6 Bandung

\section{d. Uji Linieritas dan Keberartian Regresi}

Dari hasil perhitungan didapat persamaan regresi $\mathrm{Y}$ atas X, yakni $\hat{Y}=15,58+0,997 \mathrm{X}$. Hasil pengujian linieritas uji $\mathrm{F}$ diperoleh harga $\mathrm{F}_{\text {hitung }}=$ 1,322. Selanjutnya dikonsultasikan ke tabel distribusi $\mathrm{F}$. Dari tabel didapat harga $\mathrm{F}_{(0,95)(18,25)}=$ 2,03 dan $\mathrm{F}_{(0,99)(18,25)}=2,755$. Ternyata $\mathrm{F}_{\text {hitung }}<\mathrm{F}_{\text {tabel }}$, dapat disimpulkan bahwa regresi linier diterima pada tingkat kepercayaan $95 \%$ dan $99 \%$ dengan kebebasan (dk) pembilang 18 dan penyebut 25 .

Hasil pengujian keberartian regresi dengan uji $\mathrm{F}$ diperoleh harga $F_{\text {hitung }}=11,501$. Selanjutnya dikonsultasikan ke tabel distribusi F. Dari tabel didapat harga $\mathrm{F}_{(0,95)(1,43)}=4,065$ dan $\mathrm{F}_{(0,99)(1,43)}=$ 7,255 . Ternyata $F_{\text {hitung }}>F_{\text {tabel }}$, dapat disimpulkan bahwa regresi berarti diterima.

Kesimpulan dari pengujian statistik ini, kedua variabel penelitian berdistribusi normal, linier dan arah regresi positif. Dengan demikian untuk pengujian selanjutnya digunakan statistik parametrik. 
Untuk mengetahui derajat pengaruh variabel $\mathrm{X}$ terhadap variabel Y, digunakan rumus $r^{2}=\frac{J K(T)-J K(S)}{J K(T)}$ yang didapat dari tabel ANAVA didapat $\mathrm{r}=0,596$ berada pada rentang $0,40-0,70$ yang diartikan memiliki tingkat korelasi sedang atau cukup dan hasil substitusi dengan rumus $t_{\text {student }}$ didapat hasil sebesar 4,867. Kemudian dikonsultasikan dengan $t_{\text {tabel }}$ dengan taraf kepercayaan $95 \%$ dan $90 \%$ dengan derajat kebebasan $n-2=45-2=43$, didapat nilai $t_{\text {tabel }}$ sebesar 1,68 untuk $((0,95)(43)$ dan 1,30 untuk $(0,90)(43)$. Dengan demikian koefisien korelasi dapat dinyatakan berarti dan signifikan, sehingga hipotesis penelitian dapat diterima.

\section{e. Perhitungan Koefisien Determinasi}

Untuk mengetahui besarnya persentase sumbangan pengaruh variabel satu terhadap variabel yang lainnya digunakan koefisien determinasi. Dari hasil perhitungan koefisien determinasi (KD) diperoleh harga $\mathrm{KD}=35,522 \%$. Hal ini menunjukkan bahwa variabel $\mathrm{X}$ memberikan pengaruh terhadap variabel Y sebesar 35,522 \%, sedangkan nilai sisa sebesar $64,478 \%$ hasil sumbangan dari faktor lain.

\section{Temuan Penelitian dan Pembahasan Hasil Penelitian}

\section{a. Temuan Penelitian}

Setelah dilakukan pengolahan data dengan statistik diperoleh hasil penelitian sebagai berikut :

1) Rata-rata skor siswa yang terlibat dalam kegiatan ekstrakurikuler untuk variabel $\mathrm{X}$ berada pada daerah penerimanaan tinggi. Dengan kata lain kelompok siswa yang memiliki keterlibatan dalam kegiatan ekstrakurikuler lebih banyak dari siswa yang memiliki keterlibatan sedang dan rendah. Dengan perincian kategori tinggi sebesar $68,889 \%$, kategori sedang sebesar $24,444 \%$ dan kategori rendah sebesar 6,667\%.

2) Rata-rata skor siswa yang memiliki motif berprestasi berada pada daerah penerimanaan sedang. Dengan kata lain kelompok siswa yang memiliki motif berprestasi sedang lebih banyak dari siswa yang memiliki motif berprestasi tinggi dan rendah. Dengan perincian kategori tinggi sebesar 8,889\%, kategori sedang sebesar $57,778 \%$ dan kategori rendah sebesar $33,333 \%$.
3) Hasil uji koefisien korelasi antara variabel $x$ (Keterlibatan Siswa dalam Kegiatan Ekstrakurikuler) dengan variabel Y (Motif Berprestasi Belajar Siswa) diperoleh t hitung lebih besar dari $t$ tabel pada tingkat kepercayaan $95 \%$ dan $90 \%$ dengan derajat kebebasan $(\mathrm{dk})=43$.

4) Arah serta derajat hubungan keterlibatan siswa dalam kegiatan ekstrakurikuler dengan motif berprestasi belajar siswa dinyatakan dengan koefisien korelasi sebesar 0,596 dan apabila diinterpretasikan secara garis besar berarti keterlibatan siswa dalam ekstrakurikuler mempunyai hubungan yang cukup / sedang dengan motif berprestasi belajar siswa di SMKN 6 Bandung

5) Berdasarkan hasil perhitungan koefisien determinasi dapat diketahui bahwa variabel $\mathrm{X}$ memberikan pengaruh atau sumbangan sebesar $35,522 \%$ terhadap variabel $\mathrm{Y}$ dan sisanya sebesar 64,478 dipengaruhi oleh faktor lain yang ikut menentukan motif berprestasi belajar siswa di SMKN 6 Bandung. Faktor-faktor lain yang turut berperan dalam menentukan motif berprestasi belajar siswa dalam penelitian ini tidak diteliti. Dengan demikian keterlibatan siswa dalam kegiatan eksrakurikuler hanya merupakan salah satu faktor dari sekian banyak faktor yang turut memberikan pengaruh terhadap motif berprestasi belajar siswa.

\section{b. Pembahasan}

Pembahasan hasil penelitian ini dimaksudkan untuk menganalisis secara mendalam hasil penelitian, menurut teori maupun konsep relevan. Pembahasan terhadap penelitian ini mencakup halhal sebagai berikut :

1) Gambaran Umum Keterlibatan Siswa dalam Kegiatan Ekstrakurikuler

Hasil penelitian ini menunjukkan data empirik bahwa keterlibatan siswa dalam kegiatan ekstrakurikuler tergolong pada kategori tinggi dengan proporsi $68,889 \%$. Keterlibatan siswa dalam kegiatan ekstrakurikuler ini dimanifestasikan dengan tanggung jawab dan loyalitas terhadap kegiatan ekstrakurikuler; berusaha selalu menyempatkan diri untuk menghadiri pertemuan/ latihan kegiatan ekstrakurikuler, mengikuti kegiatan ekstrakurikuler karena memiliki tujuan, baik yang bertujuan pribadi, sosial maupun akademis, siswa merasakan 
adanya manfaat yang diperoleh selama terlibat aktif dalam kegiatan ekstrakurikuler, seperti manfaat bersifat pribadi, sosial dan manfaat yang bersifat akademis, siswa merasakan adanya faktor yang menghambat dan mendukungnya dalam mengkuti kegiatan ekstrakurikuler, tapi siswa mampu mengatasi segala hambatan yang dihadapinya. Hambatan itu bersumber dari orang tua, teman, guru, fasilitas dan dari diri sendiri, dan siswa tidak mempermasalahkan apakah kegiatan ekstrakurikuler yang diikutinya berprestasi atau tidak.

Adanya kecenderungan keterlibatan siswa yang baik dalam kegiatan ekstrakurikuler, disebabkan oleh beberapa faktor, yaitu faktor dari luar diri siswa (lingkungan) dan faktor dari dalam diri siswa sendiri.

Faktor yang berasal dari luar diri siswa di antaranya : (1) adanya informasi yang dibutuhkan siswa mengenai arti, tujuan dan manfaat kegiatan ekstrakurikuler di sekolah. Adanya informasi ini menyebabkan siswa mendapat kejelasan dalam memandang dan memahami kegiatan ekstrakurikuler di sekolah. Hal ini dimanifestasikan dengan pelaksanaan kegiatan yang teratur dan terrencana, seperti waktu pelaksanaan terjadwal sehingga tidak mengganggu proses KBM, adanya pembina sebagai penanggung jawab kegiatan, adanya pengawasan, evaluasi serta pembiayan dan lain-lain, semuanya teratur dan terrencana yang disesuaikan dengan kepentingan dan kebutuhan siswa; (2) tersedianya bermacam jenis kegiatan ekstrakurikuler yang ditawarkan sekolah sehingga siswa dapat menyalurkan bakat dan minatnya pada kegiatan tertentu, berupa kegiatan bidang keolahragan, keagamaan, kesenian, kesehatan, kegiatan pengembangan seperti kepramukaan, paskibra dan kegiatankegiatan lainnya.

Faktor yang berasal dari diri siswa sendiri salah satunya adalah adanya kesadaran dari siswa untuk terlibat aktif dalam kegiatan ekstrakurikuler, walaupun kegiatan ini tidak diwajibkan dan tidak adanya penilaian dalam bentuk angka seperti dalam KBM. Dengan demikian siswa terlibat aktif dalam kegiatan ekstrakurikuler bukan karena ingin penilaian dari guru, tetapi diantaranya karena ingin mengembangkan bakat dan menyalurkan hobi dan minatnya pada kegiatan tertentu.

Dari kedua faktor (ekstrinsik dan intrinsik siswa) tersebut di atas, dapat disimpulkan bahwa adanya kecenderungan keterlibatan siswa dalam kegiatan ekstrakurikuler berkategori baik, karena adanya keselarasan antara harapan dan kenyataan. Artinya pihak sekolah dapat membantu siswa dalam menyalurkan bakat dan minatnya pada kegiatan tertentu, dengan cara menyediakan berbagai macam jenis kegiatan ekstrakurikuler. Dengan demikian siswa tinggal memilih kegiatan yang sesuai dengan keinginannya

Berdasarkan penjelasan diatas, kegiatan ekstrakurikuler sangat berguna bagi para siswa untuk mengembangkan dirinya, dalam upaya mencapai perkembangan yang optimal. Hal ini sangat berguna untuk kepentingan tercapainya tujuan pendidikan nasional. Dengan kata lain kegiatan ekstrakurikuler diperluka keberadaanya untuk membantu tercapainya tujuan pendidikan nasional yang diharapkan.

\section{2) Gambaran Umum Motif Berprestasi Siswa SMKN 6 Bandung}

Berdasarkan hasil perhitungan yang seksama terhadap data hasil penelitian, diperoleh kesimpulan motif berprestasi pada siswa di SMKN 6 Bandung pada umumnya berada pada kategori sedang dengan proporsi sebesar 57,778\%. Hal ini mengindikasikan bahwa pada umumnya motif berprestasi umumnya berkembang secara optimal.

Motif berprestasi dipengaruhi oleh berbagai faktor baik faktor internal maupun faktor eksternal. Faktor internal timbul karena individu membangkitkan motif berprestasinya sesuai dengan kondisi yang ia miliki, sedangkan faktor eksternal timbul karena motif berprestasi siswa dibangkitkan atau diperbesar oleh kondisi yang tercipta oleh lingkungan.

Motif berprestasi pada setiap siswa tingkatannya bervariasi, ada yang memiliki tingkat individu yang tinggi, adapula yang tingkatannya sedang dan rendah. Iklim sekolah yang mendukung timbulnya motif berprestasi salah satunya adalah adanya hubungan yang cukup akrab antara guru dan siswa, antara lain dukungan yang positif dari guru pembimbing kepada siswa-siswa yang aktif untuk selalu meningkatkan prestasi belajarnya. Sebaliknya apabila guru-gurunya mempunyai sifat yang otoriter dan bersikap masa bodoh, maka akan menimbulkan motif berprestasi yang rendah. Dimana indikasi siswa yang mempunyai motif berprestasi rendah sebagaimana yang diungkapkan oleh Ambo Enre Abdullkah (1979 : 27) adalah : (1) 
memberi penlaian yang rendah terhadap hasil yang diperoleh dengan kompetisi, (2) perilaku yang masa bodoh dan acuh tak acuh, (3) cenderung mengucilkan diri dan mengundurkan diri dari masalah yang dihadapinya.

Kondisi-kondisi diatas dapat dialami oleh setiap siswa jika kurang mendapat motivasi dari lingkungan, seperti jarangnya guru dan orang tua memberikan penghargan, pujian, peringatan dan hukuman secara proporsional kepada siswa baik dalam situasi belajar di kelas ataupun dalam kehidupan sehari-hari.

3) Pengaruh Keterlibatan Siswa dalam Kegiatan Ekstrakurikuler terhadap Motif Berprestasi Belajar Siswa di SMKN 6 Bandung

Hasil penelitian ini menunjukkan bahwa terdapat pengaruh yang positif dan signifikan antara keterlibatan siswa dalam kegiatan ekstrakurikuler dengan motif berprestasi pada siswa SMKN 6 Bandung, dengan koefisien korelasi $\mathrm{r}=0,596$ (korelasi sedang). Hal ini membuktikan bahwa siswa yang terlibat dalam kegiatan ekstrakurikuler, yang mengerti akan pentingnya kegiatan yang ia lakukan maka motif berprestasinyapun akan tinggi pula.

Siswa akan berusaha untuk berbuat dan memperoleh hasil yang sebaik-baiknya apabila ia terlibat dalam kegiatan ekstrakurikuler yang keterlibatannya tinggi. Ini berarti bahwa siswa yang keterlibatannya tanpa ada paksaan dari pihak manapun, yang keterlibatannya tidak sekedar ikutikutan temannya, dan memahami arti dan pentingnya kegiatan tersebut, maka ia akan memiliki dorongan untuk berbuat dan memperoleh hasil yang sebaik-baiknya, baik itu dalam kegiatan belajar mengajar di kelas maupun dalam lingkungan masyarakat sesuai dengan potensi yang dimilikinya. Sebaliknya bahwa siswa yang keterlibatannya ada paksaan dari pihak luar, yang keterlibatannya sekedar ikut-ikutan temannya, dan tidak memahami arti dan pentingnya perannya di kegiatan tersebut maka ia akan tidak memiliki dorongan untuk berbuat dan memperoleh hasil yang sebaik-baiknya.

Dari uraian di atas dapat ditarik kesimpulan bahwa keterlibatan siswa dalam kegiatan ekstrakurikuler yang tinggi sangat berpengaruh untuk mengembangk motif berprestasi, karena masih mempunyai banyak kesempatan untuk mengembangkan potensinya secara optimal.

\section{E. KESIMPULAN}

Berdasarkan landasan teoritis, hasil penelitian dan pengujian hipotesis, diambil kesimpulan sebagai berikut :

1. Secara umum keterlibatan siswa dalam kegiatan ekstrakurikuler tergolong pada kategori tinggi dengan proporsi $68,889 \%$. Keterlibatan siswa dalam kegiatan ekstrakurikuler ini dimanifestasikan dengan tanggung jawab dan loyalitas terhadap kegiatan ekstrakurikuler; berusaha selalu menyempatkan diri untuk menghadiri pertemuan/ latihan kegiatan ekstrakurikuler, mengikuti kegiatan ekstrakurikuler karena memiliki tujuan, baik yang bertujuan pribadi, sosial maupun akademis, siswa merasakan adanya manfaat yang diperoleh selama terlibat aktif dalam kegiatan ekstrakurikulerketerlibatan.

2. Secara umum siswa yang terlibat dalam kegiatan ekstrakurukuler mempunyai motif berprestasi berada pada kategori sedang dengan proporsi sebesar 57,778\%. Hal ini mengindikasikan bahwa pada umumnya motif berprestasi umumnya berkembang secara optimal.

3. Arah serta derajat hubungan keterlibatan siswa dalam kegiatan ekstrakurikuler dengan motif berprestasi belajar siswa dinyatakan dengan koefisien korelasi sebesar 0,596 dan apabila diinterpretasikan secara garis besar berarti keterlibatan siswa dalam ekstrakurikuler mempunyai hubungan yang cukup/ sedang.

\section{DAFTAR PUSTAKA}

Abin S. (2000). Psikologi Pendidikan Perangkat Sistem Pengajaran Modul, PT Remaja Rosdakarya, Bandung.

Ambo E. (1979). Pengaruh Motif Berprestasi dan Kapasitas Kecerdasan terhadap Prestasi Belajar dalam Kelompok Akademisi dalam SMA Negeri di Sulawesi Selatan, Disertasi, FPS IKIP Bandung

Dadang S. (1978). Prestasi Kecerdasan Motif Berprestasi dan Kebiasaan Belajar terhadap Prestasi Akademik Siswa SMA di Jawa Barat, Disertasi, FPS IKIP Bandung

Dedy S. (1995). Kontribusi Beasiswa terhadap Motif Berprestasi Mahasiswa dalam Penyelesaian Studi di Jurusan Pendidikan Teknik Bangunan FPTK IKIP Bandung, Skripsi, FPTK IKIP Bandung. 
Dewa S, Desak M. (1990). Pedoman Praktis Bimbingan Penyuluhan di Sekolah, Rineka Cipta, Jakarta

Eddy S. (1990). Sumbangan Sikap Orang tua pada Anak dan Peran Guru sebagai Pembimbing Terhadap Motif Berprestasi, Tesis, IKIP Bandung

Liliana., (1995). Perbedaan Motif Berprestasi Siswa Siswa Berdasarkan Latar Belakang Kemampuan Ekonomi Keluarga, Skripsi, PPB, IKIP Bandung.

Moh. Nasir. (1985). Metode Penelitian, Ghalia Indonesia, Jakarta

M. Buchari. (1978). Psikologi Sosial, Asia Baru, Jakarta

Nana S. (1991). Tuntunan Penyusunan Karya Ilmiah, Sinar Baru, Bandung

Oteng Sutisna. (1989). Administrasi Pendidikan, Dasar Teoritis untuk Praktek Profesional, Angkasa, Bandung

Peraturan Menteri Pendidikan dan Kebudayaan RI Nomor 62 tahun 2014 tentang kegiatan Ekstrakurikuler pada Pendidikan Dasar dan Pendidikan Menengah

Sanapiah F. (1982) Metodologi Penelitian Pendidikan, Usaha Nasional, Surabaya.

Sri W. (2000). Kontribusi Keterlibatan Siswa dalam Kegiatan Ekstrakurikuler terhadap Kemampuan Penyesuaian Sosialnya di Sekolah, Skripsi, PPB, UPI

Suharsimi A. (2002). Prosedur Penelitian Suatu Pendekatan Praktek, Rineka Cipta, Jakara

Sunaryo K. (1983). Kontribusi Iklim Kehidupan Keluarga dan Sekolah Terhadap Adekuasi Penyesuaian Diri, Disertasi, PPS, IKIP Bandung

Undang-undang No.20 tahun 2003 tentang Sistem Pendidikan Nasional

Winarno Surakhmad. (1990). Pengantar Penelitian Ilmiah, Tarsito, Bandung 